\title{
Increased genetic diversity in Greek populations of the genus Ligidium (Crustacea: Isopoda: Oniscidea) revealed by RFLP analysis of mtDNA segments
}

\author{
Elena Klossa-Kilia ${ }^{1}$, George Kilias ${ }^{2}$ and Spyros Sfenthourakis ${ }^{1}$ \\ ${ }^{1}$ Division of Animal Biology, Department of Biology, University of Patras, GR-26500 Patras, Greece, e-mail: \\ sfendo@upatras.gr; ${ }^{2}$ Division of Genetics, Cell and Developmental Biology, Department of Biology, University \\ of Patras, GR-26500 Patras, Greece, e-mail: kilias@upatras.gr
}

Key words: Oniscidea, Greece, mtDNA, RLFPs, genetic isolation, Ligidium, isopods, 16S rDNA, 12S rDNA

\begin{abstract}
We investigated mtDNA genetic differentiation and the phylogenetic relationships of 11 populations of the oniscidean genus Ligidium. We studied nine populations from Greece, assigned to three nominal species (L. euboicum, L. germanicum and L. beieri), and two from central Europe (L. germanicum and L. hypnorum), applying RFLP analysis of two mtDNA segments (12S rDNA and $16 \mathrm{~S}$ rDNA) amplified by PCR. The analysis revealed seven monomorphic and four polymorphic populations, and 17 different haplotypes, each one present in one population only. Several restriction enzymes produced population specific patterns, enabling discrimination among the different populations. The estimated net nucleotide divergence between populations ranges from 1.06 to $16.52 \%$, while the high $\mathrm{N}_{\mathrm{ST}}$ value $(0.96)$ indicates the existence of increased interpopulation genetic differentiation that can be attributed to the extreme isolation among Ligidium populations. The relationships between haplotypes and populations are not congruent with their geographical distribution and the established taxonomy within the genus.
\end{abstract}

\section{Contents}

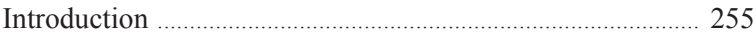

Material and methods ................................................................. 257

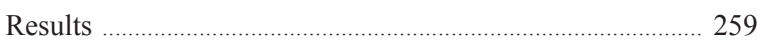

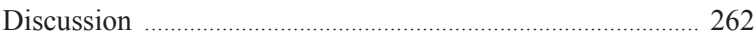

Acknowledgements ................................................................... 263

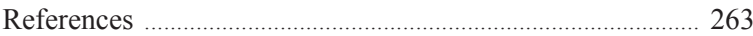

\section{Introduction}

The genus Ligidium Brandt, 1833, with 47 described species, is distributed in the northern hemisphere from West Europe to Japan and North America (Schmalfuss, 2003). Eight are endemic to Turkey, with five species restricted to the northwest of the country, six species are endemic to Greece, one is endemic to Romania, another to Bosnia, and two to the rest of Europe. The taxonomy within the genus has been based on the form of the uropods (relative length of exo- and endopodites), the shape and the number of setae on the first and the second male pleopod exopodites, and the structure of the apex of the second male pleopod-endopodite. Sfenthourakis (1993) argued that at least for the species distributed in Greece, most of these characters exhibit high intraspecific variation, and may therefore be of limited taxonomic value. The apex of the second male pleopod endopodite, an important diagnostic character, is variable. In addition, its fragile structure is easily destructed, a fact that may cause inaccurate description of its character states due to the effects of malformations, improper handling etc. As a consequence, the actual taxonomic status of Ligidium populations, especially those distributed in southern Greece, remains unclear. Furthermore, it is likely that several of the species described from the Balkans and Asia Minor are synonyms, and probably identical with some broadly distributed European species. In order to shed light on the phylogenetic relationships of populations and resolve taxonomic uncertainties of the genus, we used a molecular approach that provides additional characters and a better insight to the processes of differentiation between populations. Molecular data have been sparsely used in terrestrial isopod phylogenetics (Marcadé et al., 1999; Wetzer, 2001, 2002; Charfi-Cheikhrouha, 2003; Mattern, 2003). Molecular data (mtDNA) from selected Ligidium species have been used in analyses with a 
broader taxonomic context (Michel-Salzat and Bouchon, 2000; Mattern and Schlegel, 2001; Mattern, 2003), or serving as outgroup taxa for analysis of a related genus (Taiti et al., 2003). One of these species (L. germanicum) has been reported from Greece (Schmalfuss, 1979), but the validity of the record was questioned by Sfenthourakis (1993).

All species of the genus are hygrophilic, living in wet habitats such as the dense leaf-litter layer on riverbanks. In Greece, Ligidium is found in riparian habitats, in the wet leaf-litter layer within a narrow zone $(<3 \mathrm{~m})$ along permanent-flow streams, and in the mosses around springs and waterfalls. Thus, their populations are very sensitive to fluctuations in water flow caused by exploitation of freshwater resources for irrigation and other uses by humans. This restriction to semi-isolated habitats may have led, at least in the drier areas of Ligidium's distribution, to a pronounced metapopulational structure with limited gene flow among local populations, especially between those belonging to different river systems.

The species known from Greece are L. beieri Strouhal, 1928, L. cycladicum Matsakis, 1979, L. euboicum Matsakis, 1975, L. germanicum Verhoeff, 1901, L. ghigii Arcangeli, 1928, L. mylonasi Sfenthourakis, 1992, and L. werneri Strouhal, 1937. All

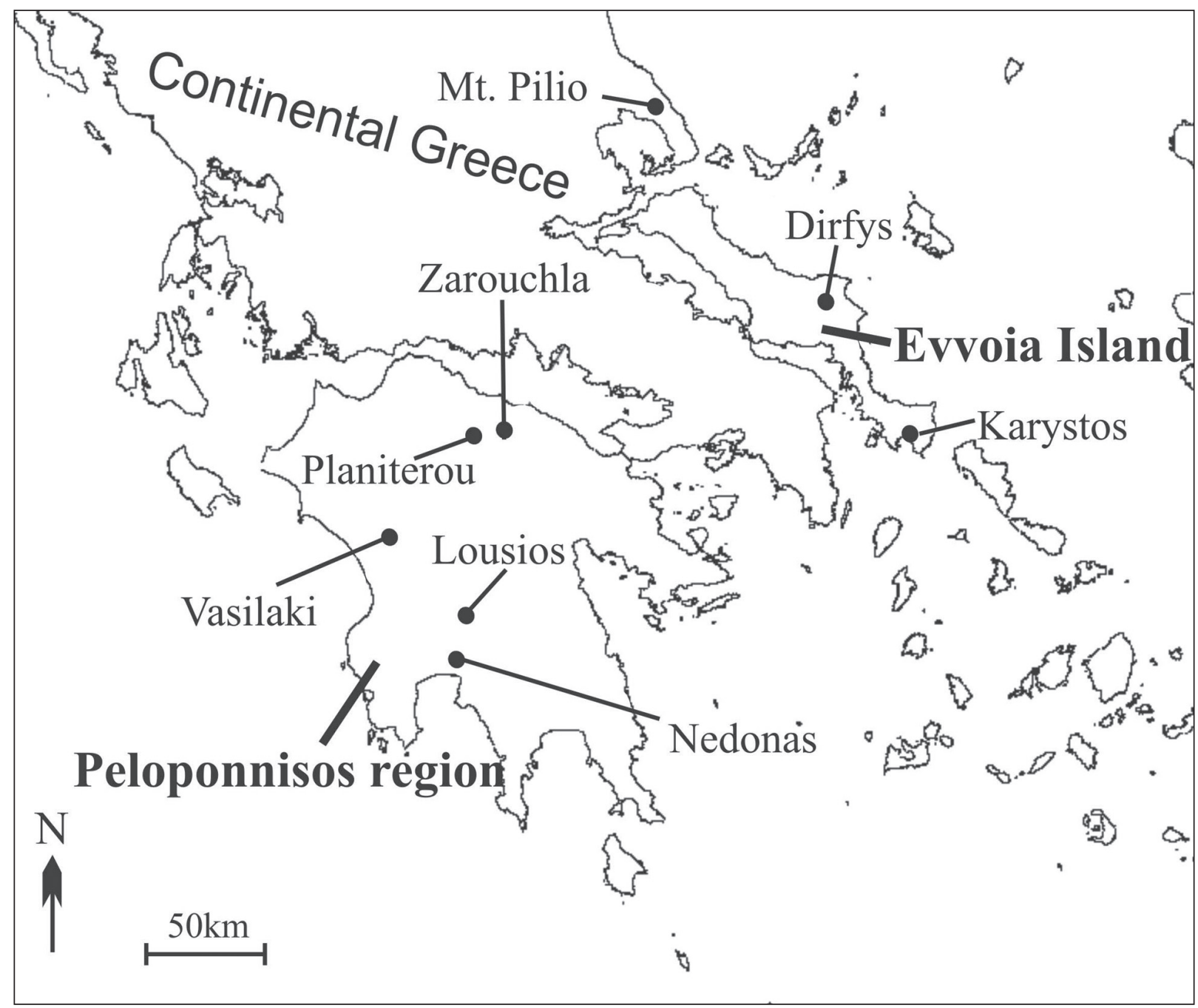

Fig. 1. Map of central Greece indicating collecting sites (dots). Evvoia Island and the semi-isolated region of Peloponnisos are indicated in bold characters. 
are endemic, except $L$. germanicum, which is widely distributed in central- eastern Europe.

As a first step in our ongoing research project, we used nine populations from Greece and two from central Europe, we analyzed two mitochondrial gene segments of the 12S - and 16S rRNA subunits, and studied the intra- and interpopulation genetic variation using RLFP analysis. Herein, we focus mainly on the populations from the almost insular region of Peloponnisos (today it is separated from the Greek mainland by the isthmus of Korinthos), since these are the most difficult to identify and they live in a piece of land that has gone through several events of isolation and reconnection to the Greek mainland (Creutzburg, 1963; Meulenkamp, 1985; Dermitzakis, 1990). According to Sfenthourakis (1993), the populations of Peloponnisos belong to L. euboicum, since male specimens seem to have the same genitalia morphology with the latter.

\section{Material and methods}

The populations of Ligidium studied herein were collected from the following locations and river systems (Fig. 1): Zarouchla (Mt. Chelmos, river

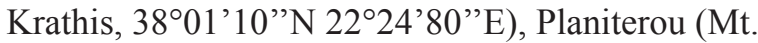
Chelmos, springs of river Ladon, 37 $59^{\prime} 10^{\prime \prime} \mathrm{N}$ $22^{\circ} 20^{\prime} 80^{\prime}$ 'E), Vasilaki (near ancient Olympia, a stream affluent of river Alfeios, 37 $38^{\prime} 00^{\prime}$ 'N $\left.21^{\circ} 41^{\prime} 10^{\prime \prime} \mathrm{E}\right)$, near Karveli (between Kalamata and

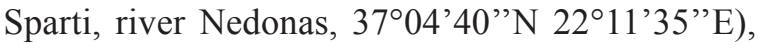
near Karytaina (river Lousios, a tributary of river

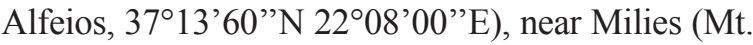

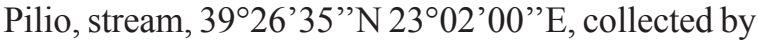
Mrs. Despoina Basakarou), Mt. Dirfys (central Evvoia Island, stream, $38^{\circ} 34^{\prime} 40^{\prime \prime} \mathrm{N} 23^{\circ} 60^{\prime} 00^{\prime \prime} \mathrm{E}$ ), two populations near Karystos (southern Evvoia Island, stream, $38^{\circ} 01^{\prime} 10^{\prime \prime} \mathrm{N} 24^{\circ} 25^{\prime} 30^{\prime \prime} \mathrm{E}$ and $24^{\circ} 25^{\prime} 50^{\prime \prime} \mathrm{E}$ ), plus one population from Slovenia (L. germanicum) and one from the suburbs of Stuttgart in southern Germany (L. hypnorum), both collected and identified by Dr Helmut Schmalfuss. All Greek populations were collected in riparian habitats, in the litter-layer of broad-leaved hygrophilous plants, mainly Platanus orientalis. The sample size used in the RFLP analysis is given in Table 3 .

All specimens were fixed and preserved in 95\% ethanol. Each specimen was grounded and total DNA was extracted from a whole individual using the DNeasy ${ }^{\circledR}$ Tissue Kit (Qiagen) following the instructions of the manufacturer with minor modifications. For the amplification of the two mtDNA segments, primers 12SCRF and 12SCRR (Lehman et al., 1995) and the universal 16Sar and 16Sbr (Palumbi et al., 1991) were used. Mitochondrial variation was investigated by restriction fragment length polymorphisms (RFLPs) performed on PCR-amplified products.

Amplifications were performed in $50 \mu \mathrm{l}$ volumes containing two units of Taq polymerase, $5 \mu 1$ of $10 \mathrm{x}$ reaction buffer provided by the manufacturer (Promega), 0.2-0.5 mM dNTPs mix, 100-200 ng DNA templates and $0.2-0.5 \mu \mathrm{M}$ of each primer. PCR amplification conditions were as follows: one preliminary denaturation step at $94^{\circ} \mathrm{C}$ for 4 min followed by $34 \mathrm{PCR}$ cycles. Strand denaturation was at $94^{\circ} \mathrm{C}$ for $15 \mathrm{sec}$, annealing at $52^{\circ} \mathrm{C}$ for $30 \mathrm{sec}$ and primer extension at $72^{\circ} \mathrm{C}$ for $1.5 \mathrm{~min}$. Final extension was at $72^{\circ} \mathrm{C}$ for $5 \mathrm{~min}$.

Amplified mtDNA segments from three individuals of each population were digested with 25 restriction enzymes in order to check for the presence of recognition sites. The informative restriction enzymes were then applied to the individuals from each population. Fourteen informative restriction enzymes were used for the 12S rDNA gene fragment (Dde I, Rsa I, Aci I, Nla III, BstN I, Alu I and Dra) and for the 16S rDNA gene fragment (Dde I, Hinf I, Hae III, Rsa I, Taq I, Nla III and Aci I).

The digested fragments were then separated electrophoretically on $2 \%$ agarose gels, in TBE buffer, stained with ethidium bromide, and visualized under UV light. The sizes of DNA fragments were compared to the PCR marker (Promega) run on the same gel. In order to identify each fragment, a letter was assigned based on order of appearance on the gel. Composite genotypes for each individual were then defined from all the restriction patterns of the mtDNA gene segments studied. The restriction fragment data were converted to restriction site data (gain or loss of restriction site) by visual inspection, as the patterns were readily recognizable.

The degree of nucleotide divergence, both between haplotypes and between populations, was estimated using the REAP computer package (McElroy et al., 1991). Three methods were used for the construction of phylogenetic trees: the Neighbour-Joining (Saitou and Nei, 1987) and UPGMA (Sneath and Sokal, 
1973) methods based on nucleotide divergence between haplotypes, as well as net nucleotide divergence between populations, available in the PHYLIP (version 3.4) computer package (Felsenstein, 1993). We also applied Dollo parsimony analysis (Farris, 1977), based on the presence or absence of restriction sites. For the application of Dollo parsimony on the population data we constructed two matrices, one with multistate characters for polymorphic states, and one coding all polymorphic states as present (since no more than three haplotypes per population were found, the possible polymorphic character state configurations were 01 , 011, and 001), which we run with PAUP* 4.0 (Swofford, 1998). The confidence of the branches was evaluated $(1,000$ replicates) by the application of the bootstrap method (Felsenstein, 1985). Trees were drawn using the TREEVIEW program (Page, 1996). ARLEQUIN (Schneider et al., 2000) was used for the calculation of the Minimum Spanning Network among haplotypes. The degree of geographical heterogeneity of mtDNA haplotype distribution was assessed using a $\chi^{2}$ statistic, as described by Roff and Bentzen (1989). The significance level was obtained by 1000 Monte Carlo randomizations using the MONTE program from the REAP package. $\mathrm{N}_{\mathrm{ST}}$ (Lynch and Crease, 1990) was used to estimate the degree of population subdivision at the nucleotide level. The resulting index gives the ratio of the average genetic distance between genes from different populations relative to that among genes in the population. Values of $\mathrm{N}_{\mathrm{ST}}$ range from 0 (no population subdivision) to 1 (complete population subdivision).

Table 1. Fragment size estimates (in base pairs) of all fragment patterns observed in the mtDNA 12S rDNA gene segment among the populations studied. (Fragments marked with asterisk were not observed but assumed under the criterion of minimum mutational steps. The presence of double zone is marked as X2.)

\begin{tabular}{|c|c|c|c|c|c|c|c|c|c|c|c|c|c|c|c|c|c|c|c|c|c|c|c|c|c|}
\hline $12 \mathrm{~S} \mathrm{r}$ & $\mathrm{DN}$ & & & & & & & & & & & & & & & & & & & & & & & & \\
\hline$\overline{\text { Dde I }}$ & & & & & Rsa I & & & Aci I & & & Nla I & & & & & BstN & & Alu I & & & Dra I & & & & \\
\hline & A & $\mathrm{BC}$ & C D & $\mathrm{EF}$ & & A B & $\mathrm{BC}$ & & $\mathrm{A}$ & B & & A & B & C D & $\mathrm{E}$ & & A B & & A & $\mathrm{BC}$ & $\mathrm{C}$ & $\mathrm{A} B$ & C D & $\mathrm{E}$ & $\bar{F}$ \\
\hline$\overline{370}$ & - & & & & 370 & - & & 280 & - & & 370 & & & & - & 370 & - & 370 & - & & 370 & - & & & \\
\hline 340 & & - & & & 320 & - & - & 220 & & - & 340 & - & & & & 200 & - & 340 & & - & 310 & - & & & \\
\hline 240 & & - & - & - & 250 & & - & 90 & - & - & 270 & & - & & & 170 & - & 175 & & & -240 & & - & - & \\
\hline 200 & & & - & & 70 & & - & 60 & & -2 & 210 & & & - & & & & 165 & & - & - 190 & & - & & \\
\hline 170 & & & - & - & 50 & - & -- & & & & 190 & & & - & & & & $30 *$ & & $-\quad-$ & -180 & & - & & - \\
\hline 130 & & - & - & & & & & & & & 180 & & & - & & & & & & & 130 & & - & - & - \\
\hline 100 & & & & - & & & & & & & 90 & & & - & & & & & & & 70 & & & - & \\
\hline 90 & & & & $\mathrm{X} 2$ & & & & & & & 70 & & - & - & & & & & & & 60 & - & & - & - \\
\hline $30 *$ & & - & & - & & & & & & & $30 *$ & - & - & & & & & & & & & & & & \\
\hline $20 *$ & & & & - & & & & & & & & & & & & & & & & & & & & & \\
\hline
\end{tabular}

Table 2. Fragment size estimates (in base pairs) of all fragment patterns observed in the mtDNA 16S rDNA gene segment among the populations studied. (Fragments marked with asterisk were not observed but assumed under the criterion of minimum mutational steps).

\begin{tabular}{|c|c|c|c|c|c|c|c|c|c|c|c|c|c|c|c|c|c|c|c|c|c|}
\hline \multicolumn{22}{|c|}{ 16S rDNA } \\
\hline \multicolumn{4}{|c|}{ Dde I } & \multicolumn{5}{|c|}{ Hinf I } & \multicolumn{2}{|c|}{ Hae III } & \multirow{2}{*}{ Rsa I } & & & & \multicolumn{2}{|c|}{ Taq I } & \multicolumn{3}{|c|}{ Nla III } & \multicolumn{2}{|c|}{ Aci I } \\
\hline & $\mathrm{A}$ & $\mathrm{BC}$ & $\mathrm{C}$ & & A & $\mathrm{B} C$ & D E & $\mathrm{F}$ & & $\mathrm{A} \mathrm{I}$ & & A 1 & B C & $\mathrm{D}$ & & $\mathrm{A}$ & & A B & $\mathrm{BC}$ & & $\mathrm{A}$ \\
\hline 230 & - & - & & 530 & - & & & & 470 & - & 530 & - & & & 460 & - & 530 & - & & 220 & - \\
\hline 200 & - & - & -4 & 490 & & - & & & 330 & & -340 & & - & & 70 & - & 350 & - & - & 140 & - \\
\hline 180 & & - & -4 & 450 & & - & & & 140 & & -260 & & - & - & & & 270 & 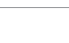 & - & 120 & - \\
\hline 110 & & - & 3 & 350 & & & - & & 60 & - & -240 & & & - & & & 180 & - & -- & 50 & - \\
\hline 100 & - & - & -3 & 320 & & & - & & & & 190 & & $-\quad-$ & & & & 80 & & - & & \\
\hline 50 & & - & -2 & 280 & & & & - & & & 80 & & - & & & & & & & & \\
\hline \multirow[t]{5}{*}{40} & & - & & 250 & & & & - & & & $30 *$ & & & - & & & & & & & \\
\hline & & & & 180 & & & - & & & & & & & & & & & & & & \\
\hline & & & & 130 & & & - & & & & & & & & & & & & & & \\
\hline & & & & 80 & & - & - & & & & & & & & & & & & & & \\
\hline & & & & 40 & & - & & & & & & & & & & & & & & & \\
\hline
\end{tabular}




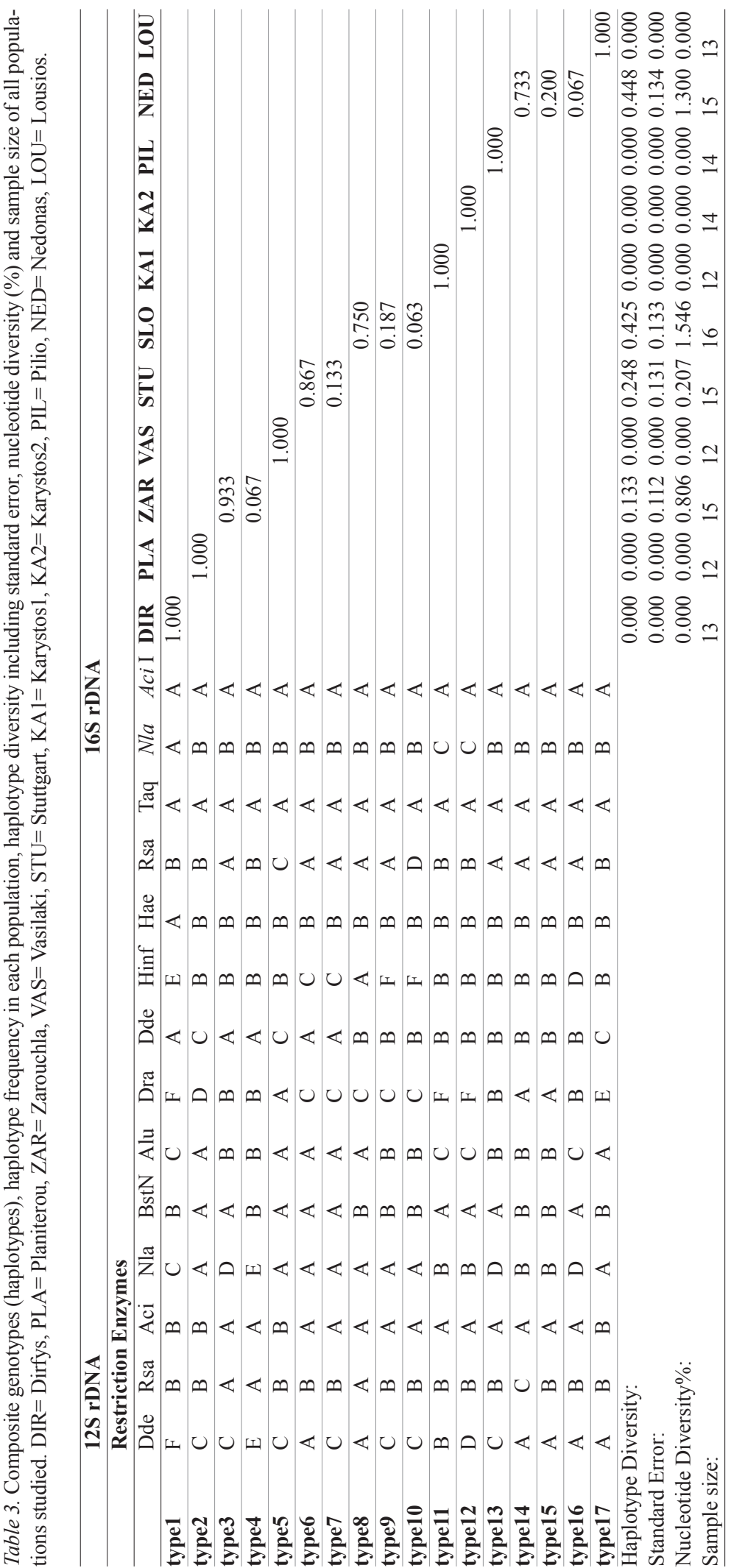

\section{Results}

The sizes of the PCR-amplified mtDNA segments for all populations studied were found to be about 370 $\mathrm{bp}$ for $12 \mathrm{~S}$ rDNA and $530 \mathrm{bp}$ for $16 \mathrm{~S}$ rDNA. Seven restriction enzymes had at least one recognition site in each of the amplified $12 \mathrm{~S}$ rDNA and $16 \mathrm{~S}$ rDNA segments. The restriction enzymes used generated a total of 40 restriction sites corresponding to an estimated fragment of 172 bp analyzed. Fragment patterns produced by each restriction enzyme for the mtDNA segments studied are shown in Tables 1 and 2.

Several restriction enzymes produced population specific patterns. More specifically, all three populations from Evvoia (L. euboicum) can be distinguished from all others by the enzymes Dde I and Dra I (12S rDNA) and Nla III (16S rDNA). The Dirfys population is distinguished from all others by Hinf I, Hae III, (16S rDNA), and Nla III (12S rDNA), while there is one restriction enzyme, Nla III (16S rDNA), that can be used for the distinction among the population of Dirfys from those of Karystos. Furthermore, Dde I (12S rDNA) is diagnostic for each one of the three populations from Evvoia. Central European populations (L. hypnorum from Stuttgart and L. germanicum from Slovenia) can be distinguished from all Greek populations by Dra I (12S rDNA) and can also be distinguished among each other by Hinf I (16S rDNA). The only continental Greek populations that have a diagnostic pattern are the one from Lousios and the one from Planiterou (Dra 12S rDNA).

The combined results from the two gene segments revealed the presence of 17 haplotypes (Table 3). Intrapopulation variation was observed in only 
Table 4. Net nucleotide divergence (\%) for mtDNA analysis among the populations studied. Abbreviations as in Table 3.

\begin{tabular}{|c|c|c|c|c|c|c|c|c|c|c|c|}
\hline & DIR & PLA & ZAR & VAS & STU & SLO & KA1 & KA2 & PIL & NED & LOU \\
\hline$\overline{\mathrm{DIR}}$ & 0.00 & & & & & & & & & & \\
\hline PLA & 10.97 & 0.00 & & & & & & & & & \\
\hline ZAR & 12.43 & 8.58 & 0.00 & & & & & & & & \\
\hline VAS & 13.67 & 2.11 & 8.13 & 0.00 & & & & & & & \\
\hline$\overline{\text { STU }}$ & 14.66 & 8.72 & 10.36 & 8.15 & 0.00 & & & & & & \\
\hline$\overline{\text { SLO }}$ & 16.52 & 10.37 & 10.09 & 9.84 & 5.00 & 0.00 & & & & & \\
\hline KA1 & 8.97 & 7.52 & 8.73 & 10.15 & 12.15 & 10.07 & 0.00 & & & & \\
\hline KA2 & 10.40 & 7.52 & 8.62 & 10.15 & 12.15 & 10.07 & 1.06 & 0.00 & & & \\
\hline PIL & 12.66 & 8.94 & 2.28 & 8.52 & 10.52 & 8.25 & 5.97 & 5.97 & 0.00 & & \\
\hline NED & 13.23 & 8.80 & 7.91 & 8.42 & 8.61 & 4.50 & 5.67 & 5.67 & 5.07 & 0.00 & \\
\hline$\overline{\mathrm{LOU}}$ & 11.35 & 5.71 & 7.96 & 5.11 & 6.75 & 6.31 & 8.29 & 8.29 & 8.60 & 7.80 & 0.00 \\
\hline
\end{tabular}

four of the 11 populations examined. Two of them revealed the presence of two haplotypes, while the remaining two revealed the presence of three haplotypes. Each haplotype was present in only one popu-

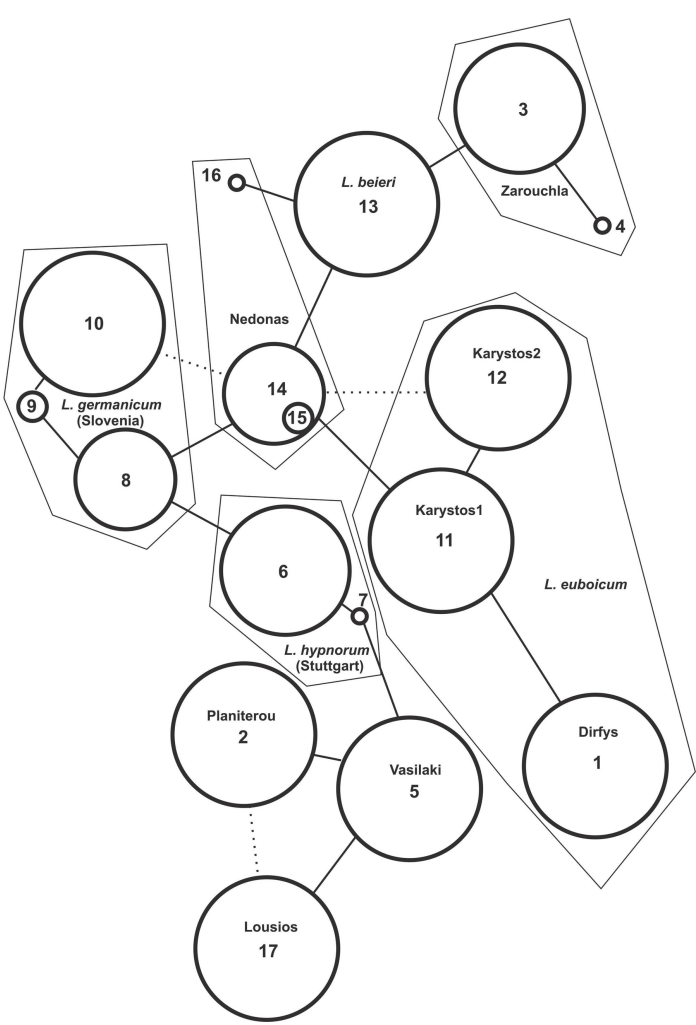

Fig. 2. The Minimum Spanning Network among haplotypes. The diameter of each cycle corresponds to the relative frequency of each haplotype. Haplotypes from the same site, or belonging to the same species, have been grouped by finer lines. Dotted lines are connections added to the Minimum Spanning Tree for the production of the Minimum Spanning Network. Numbers correspond to haplotypes as in Table 3 . lation; therefore, it is trivial to report that the differences in haplotype frequencies among populations are highly significant $\left(\chi^{2}=1510, \mathrm{P}<0.001\right)$. The Minimum Spanning Network of the 17 haplotypes is given in Fig. 2. The haplotypes (composite genotypes) detected in the populations studied, the haplotype frequencies, and the haplotype and nucleotide diversity values are given in Table 3 .

Estimated nucleotide sequence divergence among the seventeen haplotypes was found to range from 0.671 to $18.215 \%$ (data not shown). The net interpopulation nucleotide divergence estimates among the eleven populations studied varied from $1.06 \%$, between Karystos 1 and Karystos 2 (both L. euboicum), to $16.52 \%$, between Dirfys (L. euboicum) and L. germanicum from Slovenia (Table 4).

The estimated $\mathrm{N}_{\mathrm{ST}}$ value is 0.96 , a value showing that almost all genetic diversity observed was between populations, and only $4 \%$ comes from within populations.

The relationships among haplotypes according to Dollo parsimony criterion are depicted in the consensus cladogram of Fig. 3. Bootstrap values for most clades are very low, so that only a few relationships are confidently supported. For example, one haplotype of L. germanicum seems to be related more to the haplotypes of L. hypnorum than to the other haplotypes of its own species, but this clade is not supported by bootstrap. The haplotype trees produced by the Neighbour-Joining and UPGMA methods are not shown because their topology is very similar. The haplotypes of the European species, L. hypnorum (Stuttgart) and L. germanicum (Slovenia), seem to form a separate clade. Nevertheless, the relationships among Greek haplotypes are not fully resolved. The only well supported clades are: the clade of southern 


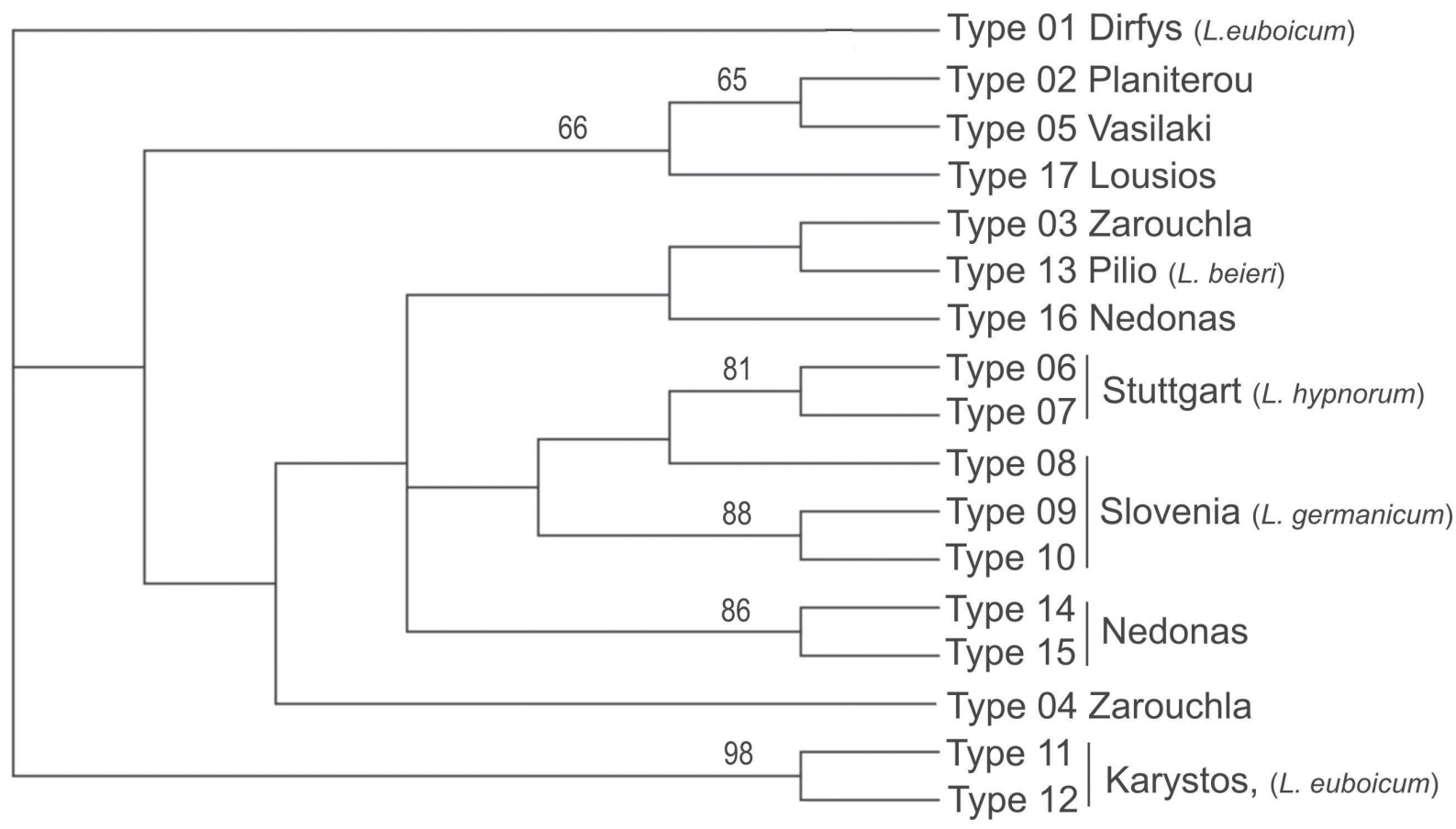

Fig. 3. The strict consensus unrooted tree of haplotypes produced from the two most parsimonious trees found (PAUP* 4.0, Dollo's parsimony, heuristic search, TBR Branch swapping algorithm). Tree length $=61$, Consistency Index (excluding uninformative characters) $=0.44$, Retention Index $=0.67$, Homoplasy Index (excluding uninformative characters) $=0.56$. Numbers on clades are percent bootstrap values larger than 50 (1,000 replicates).

Evvoia populations (Karystos 1 and 2 - L. euboicum), and the one containing haplotypes from the three monomorphic populations from central Peloponnisos (Planiterou, Vasilaki, Lousios). The groups produced by Dollo parsimony are quite different than those implied in the Minimum Spanning Network. This is probably due to increased levels of homoplasy and to the different algorithms employed by the two methods. The low explanatory value of these analyses calls for the application of additional methods, such as gene sequencing, as well as the inclusion of additional material.

The tree depicting the relationships among populations according to the Neighbour-Joining method are given in Fig. 4. Both other methods produced very similar tree topologies, therefore are not shown. We should mention only that the presence/absence coding lead to extensive polytomies, while the multistate coding lead to topologies similar to those of the other methods. The groups of populations are in general concordance with those of haplotypes. The common elements in both trees are: a) the group of three populations from Peloponnisos (Lousios, Vasi- laki, Planiterou), b) the group of Pilio and Zarouchla, c) the group of southern Evvoia (Karystos 1,2), and

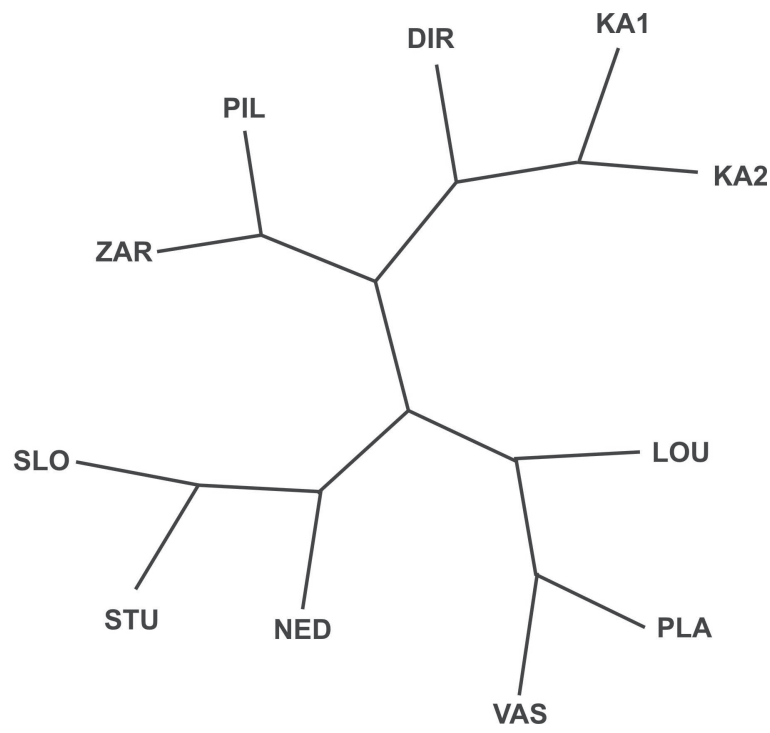

Fig. 4. The unrooted Neighbour-Joining tree of populations. Parsimony and UPGMA produced very similar topologies, therefore are not shown. Abbreviations as in Table 3. 
d) the group of European populations (L. hypnorum from Stuttgart and L. germanicum from Slovenia), despite the fact that they belong to well-established different species.

\section{Discussion}

The DNA RFLP analysis of nine Greek and two central European populations of terrestrial isopods belonging to Ligidium species revealed a strikingly high level of variation between populations, coupled with low levels of variation within populations. Each of the seventeen haplotypes found is unique in one population only. Divergence values between populations are comparable to those between species in other, phylogenetically related, animal groups. In particular, Marcadé et al. (1999) consider the 13\% divergence among populations of the species complex Porcellionides pruinosus from France and TunisiaGreece-Réunion island as indicative of the presence of separate species. A similar value (12.3\%) has been found between different species of the crustacean genus Artemia using RFLP analysis of the 16S rDNA gene segment (Gajardo et al., 2004). At the same time, genetic distance between different species of the decapod Emerita, based on nucleotide data, lies also between 13-15\% (Tam et al., 1996), while the genetic distance, according to RFLP analysis of COI and COII segments, among allopatric populations of the marine isopod Saduria entomon from northeastern Europe are lower than 2\% (Sell, 2003). In comparison, looking also at non-related taxa, divergence values around $10 \%$ have been documented for marine and estuarine populations of Atherina boyeri in Greece (Klossa-Kilia et al., 2002), which in fact are considered to be different species. Papasotiropoulos et al. (2002) have found divergence values ranging from 1.61 to 15.12 between different species of Grey Mullets (Mugilidae).

Even though there are no other data concerning genetic distance among terrestrial isopods on the basis of RFLP analysis, it is reasonable to consider that the distance values found between Ligidium populations are very high considering the geographical scale of the present analysis. These results are compatible with the biology of these animals, since they live within a narrow range of habitat types (see Introduction), forming local populations with very restricted gene flow between them.

It is remarkable that population divergence is incongruent with geographical distance among populations. Additionally, the well-established species $L$. hypnorum (Stuttgart) and L. germanicum (Slovenia) show a divergence of only $5 \%$ between them, lower than that of almost all other pairs of populations from Greece, even of populations inhabiting the same river system (Lousios and Vasilaki). Only the two populations from southern Evvoia Island (Karystos 1,2 ) show a lower nucleotide divergence, but they have been collected within a distance of less than $300 \mathrm{~m}$ and from the same river system. These populations, though, show a very high genetic distance from the population of central Evvoia (Dirfys), which belongs to the same species (L. euboicum); nevertheless they are placed in the same clades in both the population tree and the Minimum Spanning Network (MSN) of haplotypes.

The relationships among populations, as revealed by the trees of haplotypes (Fig. 3), populations (Fig. 4) and the MSN of haplotypes (Fig. 2), reveal two pertinent groups, one consisting of the insular populations from Evvoia Island (Dirfys, Karystos 1, 2), and one consisting of the three monomorphic populations from central Peloponnisos (Planiterou, Lousios, Vasilaki). Another relatively well-supported relationship is the one between the population from Mt. Pilio (L. beieri) and the one from northern Peloponnisos (Zarouchla). We should note that whereas Zarouchla and Planiterou lie close to each other from a geographical perspective, the respective Ligidium populations have been collected from rivers that flow towards different directions. The one at Zarouchla (Krathis river) flows to the north (Korinthiakos Gulf), whereas the one at Planiterou to the southwest (Ionian Sea). It seems that the populations from central Peloponnisos belong to the same stock, while those from its northern and southern part (Nedonas river) are more variable and may have a different history. Also, it is evident that it is not possible to draw a clear line between the Greek species and the European ones, even though the haplotype and the population trees suggest that European populations may belong to a distinct clade. Nevertheless, there are certain haplotypes in Greek populations that are more closely related to haplotypes of the European species. Comparing the restriction site patterns (Tables 1,2) with haplotype distribution on the MSN and the trees, 
we can see that most variation is due to the repeated and independent gain and/or loss of restriction sites. This means that there are increased levels of homoplasy in the data, probably resulting in low bootstrap values supporting the clades in these trees.

Another important finding is that the patterns of genetic divergence are not consistent with phenotypic divergence. As already stated, most morphological features of these animals are not subject to differentiation among species, while most of the characters traditionally used in the taxonomy of the genus exhibit overlapping variation (Sfenthourakis, 1993). The only dependable taxonomic character found so far, the male pleopod-endopodite 2, has the same structure in all specimens from Peloponnisos and Evvoia examined so far, whereas it differs in the specimens from Mt. Pilio (see figures in Sfenthourakis, 1993). Furthermore, this same character, as well as several other morphological features (e.g. coloration, relative length of uropod exo- and endopodite), differ strikingly between the two European populations. Genetic divergence, though, does not agree with these phenotypic patterns. We should note that, even though the present RFLP analysis has not lead to a resolution of phylogenetic relationships among populations, its results are suggestive for some discrepancy among patterns exhibited by molecular and morphological data.

The overall observations indicate an extremely high level of isolation among populations coupled with conservatism in phenotypic characters. It is not safe to translate genetic divergence in statements about phylogenetic relationships and taxonomy, since a large part of the variation is due to homoplasic changes. Further work involving more populations as well as sequence data are needed before we can resolve the phylogeny of Greek Ligidium species. On the other hand, we have shown that morphological features alone seem inadequate to reveal the standing diversity and to resolve the phylogenetic relationships inside this taxon.

\section{Acknowledgements}

We are grateful to Regina Wetzer for her eagerness to provide valuable help on methods and primers. Many thanks also to our students Filio Ioulianou and Thea Christofidou for assistance with technical work. Finally, we are obliged to Helmut Schmalfuss for sending us specimens of L. hypnorum from Stuttgart and L. germanicum from Slovenia, and to Despoina Basakarou for collecting material from Mt. Pilio.

\section{References}

Charfi-Cheikhrouha F. 2003. Genetic diversity in the mitochondrial 16S RDNA among five populations of Armadillidium pelagicum (Isopoda, Oniscidea). In: Sfenthourakis $\mathrm{S}$, Araujo PB de, Hornung E, Schmalfuss H, Taiti S, Szlavecz, $\mathrm{K}$, eds. The Biology of Terrestrial Isopods, V, Crustaceana Monographs 2: 365-380.

Creutzburg N. 1963. Paleogeographic evolution of Crete from Miocene till our days. Cretan Ann. 15/16: 336-342 (in Greek).

Dermitzakis DM. 1990. Paleogeography, geodynamic processes and event stratigraphy during the Late Cenozoic of the Aegean area. Biogeographical aspects of insularity (International Symposium, Rome 1987). Accad. Naz. Lincei 85: 263-288.

Farris JS. 1977. Phylogenetic analysis under Dollo's law. Syst. Zool. 26: $77-88$.

Felsenstein J. 1985. Confidence limits on phylogenetics: an approach using the bootstrap. Evolution 39: 783-791.

Felsenstein J. 1993. PHYLIP (Phylogeny Inference Package), Version 3.5C. Distributed by the author. Department of Genetics, University of Washington, Seattle, WA.

Gajardo G, Crespo J, Triantafyllidis A, Tzika A, Baxevanis AD, Kappas I, Abatzopoulos TJ. 2004. Species identification of Chilean Artemia populations based on mitochondrial DNA RFLP analysis. J. Biogeogr. 31: 547-555.

Klossa-Kilia E, Prassa M, Papasotiropoulos V, Alahiotis S, Kilias G. 2002. Mitochondrial DNA diversity in Atherina boyeri populations as determined by RFLP analysis of three mtDNA segments. Heredity 89: 363-370.

Lehman N, Pfrender ME, Morin PA, Crease TJ, Lynch M. 1995. A hierarchical molecular phylogeny within the genus Daphnia. Mol. Phyl. Evol. 4: 395-407.

Lynch, M, Crease TJ. 1990. The analysis of population survey data on DNA sequence variation. Mol. Biol. Evol. 7: 377-394.

Marcadé I, Souty-Grosset C, Bouchon D, Rigaud T, Raimond R. 1999. Mitochondrial DNA variability and Wolbachia infection in two sibling woodlice species. Heredity 83: 71-78.

Mattern D. 2003. New aspects in the phylogeny of the Oniscidea inferred from molecular data. In: Sfenthourakis S, Araujo PB de, Hornung E, Schmalfuss H, Taiti S, Szlavecz, K, eds. The Biology of Terrestrial Isopods, V, Crustaceana Monographs 2: 23-37.

Mattern D, Schlegel M. 2001. Molecular evolution of the small subunit ribosomal DNA in woodlice (Crustacea, Isopoda, Oniscidea) and implications for oniscidean phylogeny. Mol. Phyl. Evol. 18 (1): 54-65.

McElroy D, Moran P, Bermingham E, Kornfield J. 1991. The Restriction Enzyme Analysis Package, version 4.0. University of Maine, Orono, M.E. 
Meulenkamp JE. 1985. Aspects of the Late Cenozoic evolution of the Aegean region. In: Stanley DJ, Wezel FC, eds. Geological Evolution of the Mediterranean Basin, Springer, New York, 307-321.

Michel-Salzat A, Bouchon D. 2000. Phylogenetic analysis of mitochondrial LSU rRNA in oniscids. C.R. Acad. Sci. Paris, (Sciences de la Vie / Life Sciences) 323: 827-837.

Page RDM. 1996. TREEVIEW: An application to display phylogenetic trees on personal computers. Comput. Appl. Biosci. 12: 357-358.

Palumbi S, Martin A, Romano S, McMillan WO, Stice L, Grabowski G. 1991. The simple fools guide to PCR, version II. University of Hawaii, Honolulu.

Papasotiropoulos V, Klossa-Kilia E, Kilias G, Alahiotis S. 2002. Genetic divergence and phylogenetic relationships in Grey Mullets (Teleostei: Mugilidae) based on PCR-RFLP analysis of mtDNA segments. Biochem. Genet. 40 (3/4): 71-86.

Roff DA, Bentzen P. 1989. The statistical analysis of mitochondrial DNA polymorphisms: $\chi^{2}$ and the problem of small samples. Mol. Biol. Evol. 6: 539-545.

Saitou N, Nei M. 1987. The neighbour-joining method: a new method for reconstructing phylogenetic trees. Mol. Biol. Evol. 4: 406.

Schmalfuss H. 1979. Die Landisopoden Griechenlands. 1. Beitrag: Gattung Ligidium. Stuttg. Beitr. Nat. kd. Ser. A, 331: 1-42.

Schmalfuss H. 2003. World catalog of terrestrial isopods (Isopoda, Oniscidea). Stuttg. Beitr. Nat. kd. Ser. A., 654: 1-341.

Schneider S, Roessli D, Excoffier L. 2000. ARLEQUIN ver 2.000. A software for population genetics data analysis. Ge- netics and Biometry Laboratory, University of Geneva, Switzerland.

Sell J. 2003. Haplotype frequency distribution in northeastern European Saduria entomon (Crustacea: Isopoda) Populations. A phylogeographic approach. Int. Rev. Hydrobiol. 88: 582-593.

Sfenthourakis S. 1993. The genus Ligidium Brandt (Isopoda, Oniscidea) in Greece. Taxonomy and distribution. Biol. Gallo-Hell. 20 (1): 45-53.

Sneath PH, Sokal RR. 1973. Numerical taxonomy - The principles and practice of numerical classification. Editors Freeman WH and Co, San Francisco.

Swofford DL. 1998. PAUP*. Phylogenetic Analysis Using Parsimony (* and other methods). Version 4. Sinauer Associates, Sunderland, Massachusetts.

Taiti S, Arnedo MA, Lew SE, Roderick GK. 2003. Evolution of terrestriality in Hawaiian species of the genus Ligia (Isopoda, Oniscidea). In: Sfenthourakis S, Araujo PB de, Hornung E, Schmalfuss H, Taiti S, Szlavecz, K, eds. The Biology of Terrestrial Isopods, V, Crustaceana Monographs 2: 85-102.

Tam YK, Kornfield I, Ojeda FP. 1996. Divergence and zoogeography of mole crabs, Emerita spp. (Decapoda: Hippidae), in the Americas. Mar. Biol. 125: 489-497.

Wetzer R. 2001. Hierarchical analysis of mtDNA variation and the use of mtDNA for isopod systematics (Crustacea: Isopoda). Contrib. Zool. 70 (1): 23-39.

Wetzer R. 2002. Mitochondrial genes and isopod phylogeny (Crustacea: Isopoda). J. Crustac. Biol. 22 (1): 1-14.

Received: 6 April 2005

Accepted: 25 November 2005 